\title{
Editorial
}

\section{Omalizumab's Impact on Total and Allergen-Specific IgE Levels: A Polyclonal Story}

\author{
Julia Eckl-Dorna \\ Department of Otorhinolaryngology, General Hospital Vienna, Medical University of Vienna, Vienna, Austria
}

In 1966, Kimishige and Teruko Ishizaka [1] were the first to precipitate and characterize 'reaginic antibodies' from sera of atopic patients. As the newly identified antibody was different from the four immunoglobulin isotypes known at that time, it was designated IgE. Interestingly, preabsorption of serum from ragweed allergic patients with 'anti- $\gamma E$ ' serum raised in rabbits abolished the passive skin sensitizing activity of the serum as measured by the Prausnitz-Kuestner reaction. Thus IgE and its link to allergy were discovered.

Already in the aforementioned study, IgE-specific antibodies raised in animals were used to block the effects of IgE in experimental settings. However, it took more than 2 decades until Presta et al. [2] at Genentech developed the first humanized IgG1 antibody directed against IgE and intended for therapeutic usage in 1993. This antibody, rhuMAb-E25, also called omalizumab, was designed to bind to the $\mathrm{C} \varepsilon 3$ region of free IgE and thus block the binding of IgE to the FceRI present on mast cells and basophils. It decreases serum levels of free IgE by more than $95 \%$. From a clinical point of view, therapy with omalizumab reduces asthma exacerbations and the use of rescue medication in adults and children suffering from allergic asthma.

Interestingly, already in the first clinical studies with omalizumab, an increase in total IgE levels accompanying the rapid decrease in free serum IgE levels was noticed [3, 4]. However, the impact of omalizumab on changes in allergen-specific IgE levels has so far not been investigated. In a recent issue of the International Archives of Allergy and Immunology, Mizuma et al. [5] were the first to report changes not only in the levels of total IgE but also of allergen-specific IgE. The authors retrospectively determined changes in allergen-specific IgE levels for 11 different aeroallergens in 47 asthma patients treated with omalizumab and 30 treated with placebo. In previously sensitized patients, they observed a significant rise in allergen-specific IgE levels upon treatment with omalizumab. The changes in allergen-specific IgE levels positively correlated with baseline IgE levels.

Remarkably, using the well-established cut-off value of $0.35 \mathrm{kU} / \mathrm{l}$ for sensitization, they observed a negative-topositive seroconversion rate of up to $30 \%$ for some allergens, such as Japanese cedar, upon omalizumab treatment. The fact that seroconversion was not observed for all allergens may be due to the small sample size of 47 patients, only some of whom were not previously sensitized to the relevant allergens. Information about patients undergoing seroconversion being symptomatic for the respective allergens before showing the relevant IgE levels were only available for one allergen, Japanese cedar. All 4 patients were already suffering from pollinosis before

\section{KARGER}

E-Mail karger@karger.com

www.karger.com/iaa
(C) 2016 S. Karger AG, Basel

$1018-2438 / 16 / 1692-0069 \$ 39.50 / 0$
Correspondence to: Dr. Julia Eckl-Dorna

Department of Otorhinolaryngology, General Hospital Vienna Medical University of Vienna

Währinger Gürtel 18-20, AT-1090 Vienna (Austria)

E-Mail julia.eckl-dorna@meduniwien.ac.at 
the beginning of the study, indicating that they had already functional allergen-specific IgE antibodies but that their levels were below the cut-off level of $0.35 \mathrm{kU} / \mathrm{l}$. As the blood from 3 of the 4 patients was taken outside of the season, seasonal boost alone cannot explain the sudden detection of relevant IgE levels. It seems, therefore, that the polyclonal rise in IgE upon omalizumab therapy elevated the levels of allergenic-specific IgE that was already present - albeit at very low levels - beyond the cut-off point of $0.35 \mathrm{kU} / \mathrm{l}$ and made them 'detectable'.

One common explanation for the rise in IgE levels upon omalizumab therapy is that the relatively short halflife of free serum IgE (2-3 days) may be prolonged by binding to omalizumab, which belongs to the IgG1 subclass and has a half-life of approximately 26 days. However, there is also another potential explanation: Oma- lizumab may cross-link IgE present on the surface of IgEpositive memory B cells as B cell receptors by binding to its CE3-free regions $[6,7]$. These memory cells could be thereby activated, resulting in enhanced IgE production and total serum IgE levels. Though this current study contributes another piece to the jigsaw of understanding the rise in total IgE levels upon omalizumab therapy by showing it to be of polyclonal character, the issue regarding the underlying mechanism leading to the observed IgE rise remains unaddressed and awaits further investigation.

\section{Acknowledgment}

This work was supported by grant F4613 from the Austrian Science Fund (FWF).

\section{References}

1 Ishizaka $\mathrm{K}$, Ishizaka $\mathrm{T}$, Hornbrook MM: Physico-chemical properties of human reaginic antibody. V. Correlation of Reaginic Activity with $\gamma$ E-Globulin Antibody. J Immunol 1966;97:840-853.

2 Presta LG, Lahr SJ, Shields RL, Porter JP, Gorman CM, Fendly BM, Jardieu PM: Humanization of an antibody directed against IgE. J Immunol 1993;151:2623-2632.

3 Boulet LP, Chapman KR, Cote J, Kalra S, Bhagat R, Swystun VA, Laviolette M, Cleland LD, Deschesnes F, Su JQ, DeVault A, Fick RB Jr, Cockcroft DW: Inhibitory effects of an antiIgE antibody E25 on allergen-induced early asthmatic response. Am J Respir Crit Care Med 1997;155:1835-1840.
4 Milgrom H, Fick RB Jr, Su JQ, Reimann JD, Bush RK, Watrous ML, Metzger WJ: Treatment of allergic asthma with monoclonal anti-IgE antibody. rhuMAb-E25 Study Group. N Engl J Med 1999;341:1966-1973.

5 Mizuma H, Tanaka A, Uchida Y, Fujiwara A, Manabe R, Furukawa H, Kuwahara N, Fukuda Y, Kimura T, Jinno M, Ohta S, Yamamoto M, Matsukara S, Adachi M, Sagara H: Influence of omalizumab on allergen-specific IgE in patients with adult asthma. Int Arch Allergy Immunol 2015;168:165-172.
6 Ota T, Aoki-Ota M, Duong BH, Nemazee D: Suppression of IgE B cells and IgE binding to FceRI by gene therapy with single-chain antiIgE. J Immunol 2009;182:8110-8117.

7 Chu SY, Horton HM, Pong E, Leung IW, Chen H, Nguyen DH, Bautista C, Muchhal US, Bernett MJ, Moore GL, Szymkowski DE, Desjarlais JR: Reduction of total IgE by targeted coengagement of IgE B-cell receptor and Fc $\gamma$ RIIb with Fc-engineered antibody. J Allergy Clin Immunol 2012;129: 1102-1115. 